\title{
Natural Graphite-CVD Carbon Composites
}

\author{
S. Marinkovic*, P. W. Whang, A. Navarrete** and P. L. Walker, Jr. \\ Department of Material Sciences \\ The Pennsylvania State University \\ University Park, Pennsylvania 16802
}

(Received June 7, 1976)

\begin{abstract}
Graphite-carbon composites have been fabricated using a natural graphite powder which was molded at low pressures and room temperature and infiltrated by a CVD technique at $700^{\circ} \mathrm{C}$ using propylene as a source of carbon. The rate of removal of open porosity by carbon infiltration is proportional to open porosity up to an infiltration time of at least $24 \mathrm{hr}$. Flexural strength, Young's modulus and electrical conductivity of the composites progressively increase with increasing apparent density $(d)$, being approximated by expressions of the type $Y=a d^{b}$ over most of the infiltration range. Knoop hardness is increased by infiltration but remains much less than that found for cellulose carbon-CVD composites of comparable infiltration. Infiltration has interesting effects on CTE parallel and perpendicular to the original molding direction and CTE ratios. Heat treatment of infiltrated composites up to $2400^{\circ} \mathrm{C}$ results in density decreases and some degradation in mechanical properties.
\end{abstract}

\section{INTRODUCTION}

As has been shown previously $(1,2)$, natural graphite powders can be molded at room temperature into artifacts. Variables like molding pressure, subsequent HTT, and particle size distribution of the graphite powder affect the density and pore size distribution of the artifacts produced. However, compaction at pressures up to $9,000 \mathrm{~kg} / \mathrm{cm}^{2}$ does not decrease the surface area of the graphite, as measured by $\mathrm{N}_{2}$ adsorption at $77^{\circ} \mathrm{K}$. This means that compaction has not created apertures (slits) less than about 5.2A in thickness (3). Increasing molding pressure (increasing density) results in increasing crushing strengths and decreasing electrical resistivities for the artifacts $(1,2)$. However, reactivity of artifacts to $\mathrm{CO}_{2}$ at $800^{\circ} \mathrm{C}$ is unaffected by previous molding pressures (1).

Recently we have reported on the preparation of composites by the infiltration of porous cellulose carbon artifacts with CVD carbon from propylene (4). The cellulose carbon artifacts (substrates) prepared by molding at room temperature, curing at $250^{\circ} \mathrm{C}$, and carbonizing at $800^{\circ} \mathrm{C}$ consisted of a disordered carbon structure and exhibited isotropic properties. A reasonably high transverse breaking strength $\left(100 \mathrm{~kg} / \mathrm{cm}^{2}\right)$ for the uninfiltrated artifact, despite its low density $(0.7 \mathrm{~g} / \mathrm{cc})$, suggested that some particle consolidation had occurred during the carbonization step. This consolidation could be the result of cross linking reactions occurring during curing of the cellulose.

* Present address, Boris Kidric Institute, Belgrade, Yugoslavia. ** Present address, Universidad De Granada, Granada, Spain.
It was, therefore, of practical and scientific interest to study the preparation of composites from the CVD infiltration of molded natural graphite artifacts. Practically, such composites may have application where anisotropic properties are desired. Scientifically, it is of interest to compare rates of CVD over substrates as markedly different in structure as cellulose carbon and natural graphite.

\section{EXPERIMENTAL}

\subsection{Preparation of uninfiltrated artifacts}

Natural graphite powder (SP-1 grade from the Carbon Products Division of Union Carbide Corporation) was used as the starting material. It had a total impurity content of less than $6 \mathrm{ppm}$ and a specific BET surface area of $1.8 \mathrm{~m}^{2} / \mathrm{g}$, as measured by $\mathrm{N}_{2}$ adsorption at $77^{\circ} \mathrm{K}$. From quantitative $\mathrm{x}$-ray diffraction studies on the (004) diffraction peak, the interlayer spacing of the material was $3.3541 \mathrm{~A}$ at $15^{\circ} \mathrm{C}$. Microscopic investigation revealed the powder to be composed of flake-like particles having a mean diameter of $30 \mu$ on a number basis. The particle thickness is estimated as $0.5 \mu \mathrm{m}$ (5).

In order to produce artifacts with a large open porosity, the graphite powder was molded into bars at a low pressure, that is $370 \mathrm{~kg} / \mathrm{cm}^{2}$. The bars had dimensions of $10.9 \mathrm{~cm}$ long, $1.2 \mathrm{~cm}$ wide, and $0.35 \mathrm{~cm}$ thick, with the thickness dimension parallel to the molding direction. The bars had an apparent density of $1.65 \mathrm{~g} / \mathrm{cc}$ or an open porosity (based on a helium density for the graphite powder of $2.25 \mathrm{~g} / \mathrm{cc}$ ) of $36.2 \%$. This is to be compared with an open porosity of $62 \%$ in the unin- 
filtrated cellulose carbon artifacts used in the previous CVD studies (4). Molding resulted in some preferred orientation of the graphite particles, with their long dimension perpendicular to the pressing direction. That is, the (002) peak intensity ratio for two mutually perpendicular directions $\left(I_{002}^{I} / I_{002}^{T}\right)$, see reference 6 , had a value of 11.3

\subsection{Infiltration conditions}

A $50 \%$ propylene-50\% helium mixture (by volume) was used at atmospheric pressure and $700^{\circ} \mathrm{C}$ for infiltration, as previously described (4). This temperature was selected previously since infiltration for $72 \mathrm{hr}$ did not result in noticeable external surface deposition. The gas mixture was passed in laminar flow through the reactor, it having a residence time of $4 \mathrm{~min}$ in the $46 \mathrm{~cm}$ hot zone, as previously described (4). Up to four samples could be infiltrated at one time.

\subsection{Measurement of sample properties}

All properties were measured using approaches similar to those described previously to characterize the cellulose-CVD composites (4).

\section{RESULTS AND DISCUSSION}

\subsection{Kinetics of the CVD process}

As found previously (4), the rate of decrease in open porosity upon infiltration of the artifacts was proportional to the fraction of open porosity $(\theta)$ present in the sample at time $(t)$ over most of the run. That is, $-d \theta / d t=k \theta$. Up to $24 \mathrm{hr}$ infiltration time, the first order plot of $\log \left(100 \theta_{t} / \theta_{0}\right)$ vs time was linear, having a slope of $-0.0137 \mathrm{hr}^{-1}$. This is to be compared with a slope of $-0.00877 \mathrm{hr}^{-1}$ found for the first order plot for infiltration of the cellulose carbon artifact.

Figure 1 presents results for the weight of carbon pick-up versus time on the natural graphite and cellulose artifacts. Results are normalized by dividing the weight of carbon deposited by the initial weight of the artifact used. Interestingly, up to about $24 \mathrm{hr}$ infiltration time, the rate of carbon pick-up on the natural graphite is greater than that on the cellulose carbon, despite the fact that their initial total surface areas, as measured by $\mathrm{N}_{2}$ adsorption at $77^{\circ} \mathrm{K}$, are 1.8 and $480 \mathrm{~m}^{2} / \mathrm{g}$, respectively. Studies in progress in this laboratory are showing, however, that it is not the total surface area (TSA) but the active surface area (ASA) which determines the rate of propylene cracking. The active area is located at the prismatic faces of carbon crystallites and around point defects within the basal plane. On the basis of our recent studies in this laboratory on the cracking of propylene over activated Graphon, the disappearance of propylene is first order in propylene pressure with a rate constant at $700^{\circ} \mathrm{C}$ of $8.3 \times 10^{-5} \mathrm{~cm} / \mathrm{sec}$. To calculate this rate constant, the ASA of the Graphon was measured by oxygen chemisorption at $300^{\circ} \mathrm{C}(7)$. Using this value and the rate expression

$$
\text { Rate }=\left(k_{973}\right)\left(C_{\mathrm{C}_{3} \mathrm{H}_{6}}\right)(\text { ASA })
$$

where $k_{973}$ is the rate constant and $C_{\mathrm{C}_{3} \mathrm{H}_{6}}$ is the concentration of propylene flowing through the reactor over the graphite artifacts, it is possible to predict an initial rate for carbon deposition over the SP-1 graphite. If the ASA of SP-1 graphite is taken as $3.7 \%$ of the TSA (5) and if $50 \%$ of the carbon in the propylene molecule goes to deposited carbon and 50\% to methane and

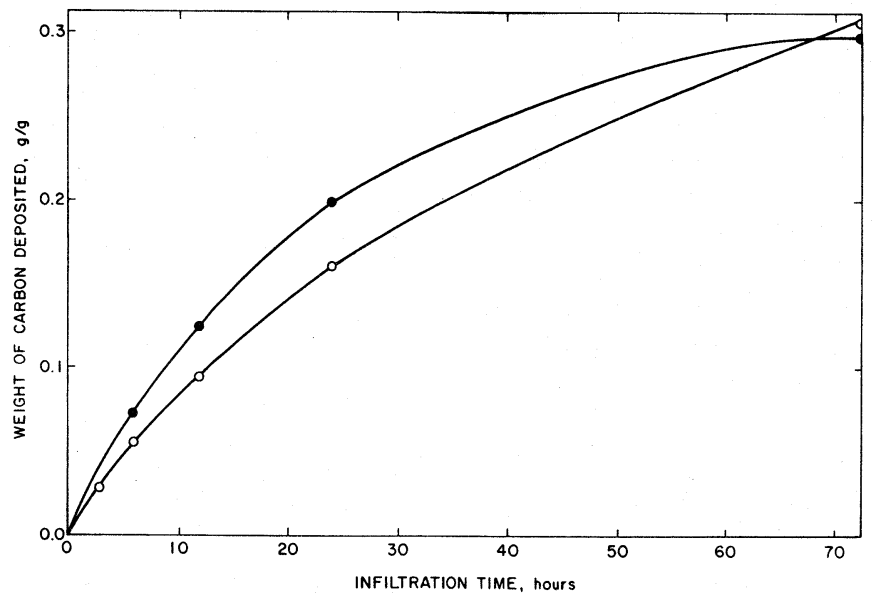

Fig. 1 Rate of infiltration of ( $\bullet$ ) graphite and $(O)$ cellulose artifacts with carbon from propylene at $700^{\circ} \mathrm{C}$. 
ethylene (as is roughly found), the initial rate of carbon deposition is predicted to be $2.3 \times 10^{-2} \mathrm{~g} / \mathrm{g} \mathrm{hr}$. This agrees reasonably well with the estimated initial slope for the plot of carbon deposition over SP-1 graphite in Figure 1 - that is $1.6 \times 10^{-2} \mathrm{~g} / \mathrm{g} \mathrm{hr}$.

The possible role which diffusional resistance plays in limiting the rate of carbon deposition can be estimated from the dimensionless criteria, $\phi^{2} \eta$. That is (8)

$$
\phi^{2} \eta=\left(\frac{R}{C_{\mathrm{C}_{3} \mathrm{H}_{6}} D_{\text {eff }}}\right)\left(\frac{d W}{d t}\right)
$$

where $R$ is one-half the sample dimension in the direction where diffusion should be most rapid (taken as one-half the width dimension in this case), $D_{\text {eff }}$ is the effective diffusion coefficient, and $d W / d t$ is the rate of propylene cracking per unit external area. $D_{\text {eff }}$ is calculated for the counter-diffusion of propylene in hydrogen and is corrected for tortuosity $\left(\cos 45^{\circ}\right)$ and sample porosity $(0.362)$. At $700^{\circ} \mathrm{C}, \phi^{2} \eta$ is estimated to equal $1.2 \times 10^{-2}$, which is significantly $<0.1$. The significance of $\phi^{2} \eta<0.1$ is that under these circumstances the rate of a heterogeneous gas-solid reaction is chemically controlled (8). Therefore, we conclude that diffusional resistance to the initial rate of carbon infiltration of the SP-1 graphite artifacts was negligible.

The fact that the rate of carbon infiltration in the SP-1 graphite was greater than that in the cellulose carbon might be explained by three possibilities: i) SP-1 graphite has a higher inorganic impurity content which might catalyze the reaction, ii) SP-1 graphite has a higher ASA, and iii) infiltration of the cellulose artifact was diffusion limited. The first possibility is ruled out because of the very high purity of SP-1 graphite and close agreement in deposition rate with that predicted from studies using Graphon. Because of its smaller crystallite size and more defective structure, the ASA of cellulose carbon is expected to be higher than that of SP-1 graphite, suggesting that possibility (ii) should be ruled out. It is concluded that infiltration into the cellulose carbon artifacts was diffusion limited. The asformed cellulose artifact exhibited molecular sieve properties in the uptake of $\mathrm{N}_{2}$ and $\mathrm{CO}_{2}$ (4); and, therefore, it is concluded that much of the internal surface area was located in voids between about 4.9 and $5.2 \mathrm{~A}$ in size. Indeed, infiltration for only $3 \mathrm{hr}$ sharply reduced the internal $\mathrm{N}_{2}$ surface area in the cellulose artifact from 480 to $4 \mathrm{~m}^{2} \mathrm{~g}$ (4).

\subsection{Effect of carbon infiltration on composite properties}

As with the cellulose composites (4), changes in flexural strength $(\sigma)$, Young's modulus $(E)$, and electrical resistivity $(\rho)$ with changes in apparent density upon infiltration can be expressed by log-log plots, as seen in Figure 2. Experimental points for $\sigma$ and $E$ fit linear plots reasonably well, except at low levels of infiltration, where the artifacts are quite weak. Values of $\sigma$ also fall below the line following infiltration for $72 \mathrm{hr}$. This is attributed to noticeable build-up of deposited carbon at the exterior surface of the artifact, as previously discussed (4). Infiltration of the graphite artifacts produced much greater proportionate increases in $\sigma$ and $E$ than did infiltration of the cellulose artifacts, for similar extents of carbon pick-up. For the graphite artifact, following $72 \mathrm{hr}$ of infiltration, $\sigma$ increased from about 4 to $500 \mathrm{~kg} / \mathrm{cm}^{2} ; E$ increased from about $2.5 \times 10^{4}$ to $4.0 \times 10^{5} \mathrm{~kg} / \mathrm{cm}^{2}$. By contrast, $72 \mathrm{hr}$ infiltration of the cellulose artifact increased $\sigma$ from 100 to $800 \mathrm{~kg} / \mathrm{cm}^{2}$ and $E$ from $1.7 \times 10^{4}$ to $2.0 \times 10^{5} \mathrm{~kg} / \mathrm{cm}^{2}$.

Conversely, infiltration of the graphite artifact produced a smaller decrease in $\rho$ than infiltration of the cellulose artifact. Following carbon deposition for 72 $\mathrm{hr}, \rho$ decreased from 4.6 to $1.2 \mathrm{mohm} \cdot \mathrm{cm}$ for the former and from 200 to $29 \mathrm{mohm} \cdot \mathrm{cm}$ for the latter. The extent of the change in properties of these two artifacts upon infiltration is consistent with two facts.

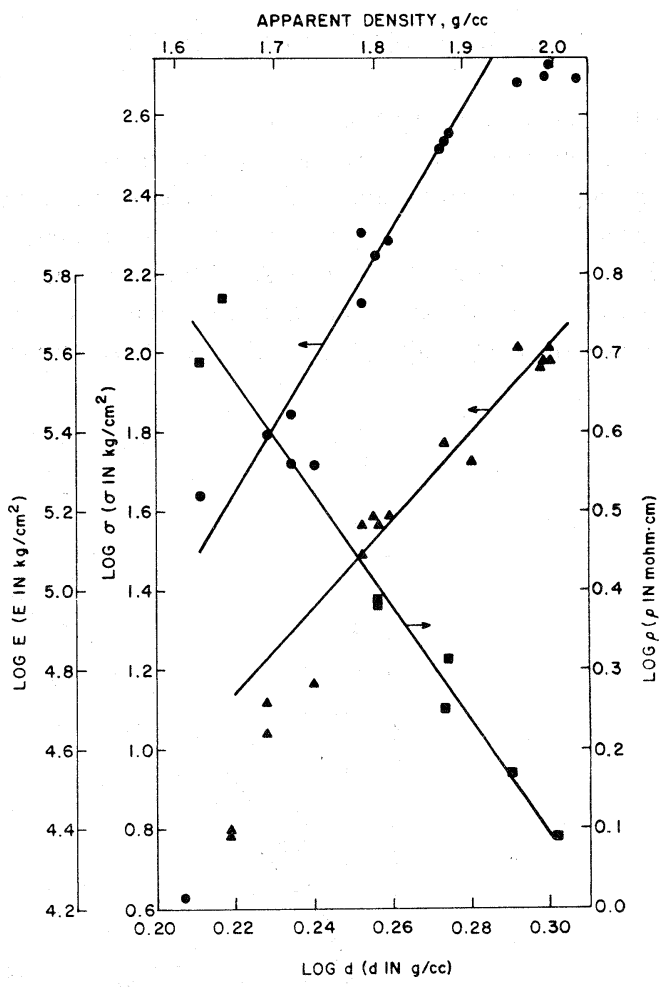

Fig. 2 Dependence of flexural strength ( ), Young's modulus ( $\mathbf{\Delta})$, and electrical resistivity ( $\mathbf{Q})$ upon apparent density of composites. 
Table 1 Selected properties of infiltrated graphite artifacts

\begin{tabular}{c|r|c|c|c|c|r}
\hline \multirow{2}{*}{$\begin{array}{c}\text { Infiltration } \\
\text { time, hr }\end{array}$} & \multicolumn{2}{|c|}{$\begin{array}{c}\text { Knoop } \\
\text { hardness } \\
\mathrm{kg} / \mathrm{cm}^{2}\end{array}$} & \multicolumn{2}{|c|}{$\begin{array}{c}\text { Wear } \\
\text { gm/500 revol. }\end{array}$} & \multicolumn{3}{|c}{$\mathrm{CTE} \times 10^{6},{ }^{\circ} \mathrm{C}^{-1}$} \\
\cline { 2 - 5 } & \multicolumn{1}{|c|}{$\perp$} & $\|$ & & $\perp$ & $\|$ & $\| / \perp$ \\
\hline 6 & 11.1 & 22.8 & - & 0.37 & 11.2 & 30.2 \\
12 & $<10.0$ & 24.0 & - & 0.46 & 69.5 & 150.0 \\
24 & 19.4 & 22.8 & - & 1.64 & 82.3 & 50.2 \\
72 & 43.2 & 47.2 & 1980 & 3.58 & 35.8 & 10.0 \\
\hline
\end{tabular}

First, the CVD carbon is less crystalline and more disordered than the natural graphite but more crystalline and less disordered than the cellulose carbon. Second, in the uninfiltrated cellulose artifact, some bonding has taken place between particles; it behaves like a consolidated body. By contrast, particles in the uninfiltrated graphite artifact are attracted by weak van der Waals forces; it behaves like an unconsolidated body.

Table 1 summarizes the effect of carbon infiltration on other important properties. Even though infiltration increases the hardness of the graphite artifact, its hardness is much less than that for the cellulose body. For example, infiltration for $72 \mathrm{hr}$ only results in a Knoop hardness of about $45 \mathrm{~kg} / \mathrm{cm}^{2}$ compared to 186 $\mathrm{kg} / \mathrm{cm}^{2}$ for the infiltrated cellulose artifact. Wear resistance is poor, that is $1980 \mathrm{mg}$ weight loss following 500 revolutions for the $72 \mathrm{hr}$ infiltrated sample. By contrast, the infiltrated cellulose sample, underwent a weight loss of only $3.0 \mathrm{mg}$ in 500 revolutions. This latter figure for wear resistance is superior to that found for stainless steel.

Effects of infiltration on the coefficient of thermal expansion (CTE) between 20 and $400^{\circ} \mathrm{C}$ are interesting. As expected because of crystallite alighment produced upon molding of the graphite artifacts, CTE parallel to the molding direction is larger than that perpendicular to the molding direction. However, since CTE $(\perp)$ monotonically increases with increasing extent of infiltration whereas CTE ( $\|)$ goes through a pronounced maximum with increasing infiltration, the ratio of CTE's $(\| / \perp$ ) goes through a pronounced maximum. Generally, the CTE of artifacts increases as the void volume existing between particles and crystallites (which can take up crystallite thermal expansion) decreases. However, in this case it is apparent that the deposition of sufficient CVD carbon, in effect, encapsulated individual graphite particles and retarded their normal expansion in the $c$-axis direction.

\subsection{Effect of heat treatment on composite properties}

As seen in Table 2, heat treatment (HT) decreased the densities of the infiltrated graphite artifacts. Artifact weight and planar dimensions did not change by more than $0.2 \%$ upon $\mathrm{HT}$ to $2400^{\circ} \mathrm{C}$; on the other hand, sample thickness increased substantially more (up to $2.8 \%$ ) and was responsible for most of the density decrease.

Heat treatment resulted in some degradation of mechanical properties. For example, $\sigma$ for the $72 \mathrm{hr}$ infiltrated sample fell from 500 to $400 \mathrm{~kg} / \mathrm{cm}^{2}$ following HT to $2400^{\circ} \mathrm{C}$. Young's modulus fell from $4.0 \times 10^{5}$ $\mathrm{kg} / \mathrm{cm}^{2}$ to $3.0 \times 10^{5} \mathrm{~kg} / \mathrm{cm}^{2}$. Such decreases are greater than would be expected on the basis of the decrease in artifact density as a result of HT and is attributed to some graphitization of the CVD carbon, as was previously reported (4).

As is seen in Table 3, HT drastically decreased the hardness of the artifacts. It also made wear resistance

Table 2 Effect on heat treatment on density of infiltrated graphite artifacts

\begin{tabular}{c|c|c}
\hline \multirow{2}{*}{$\begin{array}{c}\text { Infiltration } \\
\text { time, hr }\end{array}$} & \multicolumn{2}{|c}{ Density decrease, \% } \\
\cline { 2 - 3 } & $1500^{\circ} \mathrm{C}$ & $2400^{\circ} \mathrm{C}$ \\
\hline 6 & 0.8 & 2.1 \\
12 & 0.8 & 3.1 \\
24 & 1.4 & 4.1 \\
72 & 0.5 & 3.4 \\
\hline
\end{tabular}

Table 3 Effect of heat treatment on selected properties on infiltrated graphite artifacts

\begin{tabular}{c|c|c|c|c|c|c|c|c|c|c}
\hline \multirow{2}{*}{$\begin{array}{c}\text { Infiltration } \\
\text { time, hr }\end{array}$} & \multicolumn{3}{|c|}{ Knoop hardness, $\mathrm{kg} / \mathrm{cm}^{2}$} & \multicolumn{5}{c}{$\mathrm{CTE} \times 10^{6},{ }^{\circ} \mathrm{C}^{-1}$} \\
\cline { 2 - 11 } & \multicolumn{2}{|c|}{$1500^{\circ} \mathrm{C}$} & \multicolumn{2}{|c|}{$2400^{\circ} \mathrm{C}$} & \multicolumn{3}{|c}{$1500^{\circ} \mathrm{C}$} & \multicolumn{3}{|c}{$2400^{\circ} \mathrm{C}$} \\
\cline { 2 - 11 } & $\perp$ & $\|$ & $\perp$ & $\|$ & $\perp$ & $\|$ & $\| / \perp$ & $\perp$ & $\|$ & $\| / \perp$ \\
\hline 6 & $<10$ & $<10$ & $<10$ & $<10$ & 0.21 & 15.1 & 71.9 & 0.28 & 12.3 & 43.9 \\
12 & $<10$ & $<10$ & $<10$ & $<10$ & 0.23 & 8.97 & 39.0 & 0.36 & 7.61 & 21.1 \\
24 & 18.9 & 19.9 & $<10$ & $<10$ & 0.20 & 7.26 & 36.3 & 0.12 & 3.41 & 28.4 \\
72 & 21.4 & 25.4 & 12.9 & 16.5 & 0.25 & 2.50 & 10.0 & 0.16 & 2.47 & 15.4 \\
\hline
\end{tabular}


too low to measure. HT also markedly lowered CTE's in both the parallel and perpendicular directions, as well as the maximum ratio of the CTE's found in these directions. These results can qualitatively be explained on the basis of crystallite growth in the CVD carbon and significant permanent expansion in the composites in the direction parallel to molding as a result of HT. Clearly there is no incentive to heat treat CVD infiltrated graphite artifacts on the basis of these results.

\section{Acknowledgements}

This study was supported by the Advanced Research Projects Agency on Contract No. DAH15 71 C 0290. The SP-1 natural graphite was kindly supplied gratis by the Carbon Products Division, Union Carbide Corporation.

\section{REFERENCES}

1) F. Rusinko, Jr. and P. L. Walker, Jr., Proceedings of the Fourth Conference on Carbon, Pergamon Press, Oxford, 1960, p. 751.

2) S. M. Kemberling and P. L. Walker, Jr., Tanso, No. 52, 2 (1968)

3) P. L. Walker, Jr., L. G. Austin, and S. P. Nandi, Chemistry and Physics of Carbon, Vol. 2, Marcel Dekker, New York, 1966, p. 257.

4) S. Marinkovic, P. W. Whang, A. Navarrete, and P. L. Walker, Jr., Tanso, No. 84, 7 (1976).

5) P. L. Walker, Jr., L. G. Austin, and J. J. Tietjen, Chemistry and Physics of Carbon, Vol. 1, Marcel Dekker, New York, 1965, p. 327.

6) P. L. Walker, Jr., R. P. Gardner, M. A. Short, and L. G. Austin, Proceedings of the Fifth Carbon Conference, Vol. 2, Pergamon Press, Oxford, 1963, p. 483.

7) N. R. Laine, F. J. Vastola, and P. L. Walker, Jr., J. Phys. Chem., 67, 2030 (1963).

8) P. L. Walker, Jr., Frank Rusinko, Jr., and L. G. Austin, Advances in Catalysis, Vol. 11, Academic Press, New York, 1959, p. 133.

学振第 117 委員会第 140 回会議

学振第 117 委員会第 140 回会議が, 昭和 51 年 7 月 15 日(木)，16日(金)の両日, 東京神田学士会館において開 催された。 A, B , Cの各分科会に下記の資料が提出さ れ，活発な討論が交わされた。

117-140-A-1 石油系重質油の炭化に関する研究

- o-Phenanthroline と S/L saturates の混合炭化 -

（興垔石油）角田三尚ほか

117-140-A-2 Structural Change of Hard Carbon under High Pressure (名大工) S. de Fonton ほか 117-140-A-3 酸化硼素を添加した石油コークスの加 熱処理に伴う X 線パラメーター変化

（九工試）小林和夫ほか

117-140-A-4 コークスー炭化硼素のホットプレス焼 結体 (九工試) 宮崎憲治ほか

117-140-B-1 フィラメントワインディング成形法に
よる炭素繊維一炭素複合材料の試作とその気孔率

（東工大）田中英彥ほか

1'17-140-B-2 原子炬用黒鉛の気孔率測定に関する二， 三の試みについて

（原研）佐々木泰一ほか

117-140-C-1 メソフェースを含むピッチから作った 炭素繊維の構造 第 I 報 （信大工）遠藤守信ほか 117-140-C-2 黒鉛繊維一硝酸残存化合物の生成と電 気的特性

（信大工）遠藤守信ほか

117-140-C-3 液体へリウム温度および同温度以下に おけるコークスの異常磁気抵抗

（武蔵工大）菱山幸宥ほか 117-140-C-4 乱層構造炭素の電子的性質

（日大理工）江森徹男ほか

117-140-C-5 黒鉛の電流磁気効果

（日大理工）河村 清ほか 